\title{
Gondolatok a tanár mentális jóllétének aspektusairól és azok hatásairól
}

\author{
Borbáth Katalin \\ Pécsi Tudományegyetem „Oktatás és Társadalom” Doktori Iskola \\ doktotandusz
}

Az iskola világát áthatják az érzelmek, és ezalól a pedagógusok érzései sem kivételek, amelyek jelentősen befolyásolják az iskolai klímát és a diákok teljesítményét is. A téma iránti érdeklődést mutatja, hogy differenciálódtak a pedagógusok mentálhigiénés állapotának vizsgálatát célzó felmérések: hagyományosan kiégés és újabban pszichés jóllét szempontú kutatásokra. Ezen kutatások aktuális, főként hazai elemeit mutatja be a tanulmány, bemutatva ezen vizsgálatok releváns eredményeit a pedagógusok szakmai és érzelmi életének hátteréről, kitérve a kiégés veszélyeztetettség és a szakterület, a pedagógiai, és pszichológiai ismeretek, valamint az életszemlélet és a flow tanórai megélése közötti összefüggésekre. Bemutatja a cikk azt a folyamatot is, amely a mindeközben fontossá vált tanári személyiségjellemzők kutatása területén zajlik, ahol elsősorban a pozitív pszichológia és személyiségpszichológia legújabb elméleteinek neveléstudományra tett erőteljes hatása nyomán világossá vált, hogy a tanárok személyiségjellemzői, a szakmai és személyes én szintén fontos faktorai a tanárok identitásának. Végül - összefüggést találva a pedagógusok érzelmi állapota és a tanárképzés egyes elemei között - az írás kitér korunk egyik legsikeresebb, sokszor példaként emlegetett finn tanárképzési modell azon elemére, melyben a pedagógus identitás, a szakmai személyiség tudatos kialakítása is megtörténik, és nem (csak) elméleti szinten jelenik meg a képzésben az önismeret, a szakmai személyiség mint téma, hanem konkrét pedagógiai cselekmény részeként alakul ki.

Kulcsszavak: pedagógus, kiégés, pszichés jóllét

Az elmúlt évtized neveléstudományi kutatásaiban megnőtt az érdeklődés az iskola diákokra gyakorolt érzelmi hatását illetően. Az eredmények meglehetősen negatív képet festenek. Koncz István (2008) egyenesen rémálomnak nevezte az iskolát a gyerekek számára, és ebben a legfőbb okként a pedagógusokat jelölte meg. Ezt a képet erősíti a fekete pedagógiaként elnevezett hatás, amely általában a pedagógusok gúnyos, megbélyegző megnyilvánulásaiban érhető tetten. A fekete pedagógia művelésének gyakorlatához is köthető az a jelenség, hogy a szükségletorientált, érzelmi fókuszú nevelés hiányzik az 
iskolákból. Ez a hiány az oka a mobbing vagy iskolai zaklatás jelenlétének és terjedésének a iskolai érzelmekkel foglalkozó kutatások szerint (Hunyadyné \& M. Nádasi, 2008).

Az aggasztó iskolai szociálpszichológiai jelenségek felszínre kerülésével és ezek tanulmányozásával egyértelműen kimondható, hogy az érzelmek fontosak és figyelmet érdemelnek az iskolában is. Felmerül a kérdés, milyen tényezők függenek össze a gyerekek érzelmi állapotával, általános jóllétével? Logikus, hogy a legfőbb iskolai aktorok tekintetében is összefüggést keressünk, a pedagógus érzelmi állapota és mentális jólléte is különös figyelmet érdemel.

Jelen tanulmány a pedagógusok jóllétének jellegzetességeinek számos aspektusát mutatja be. Nemzetközi kitekintésben áttekinti a legfontosabb kutatásokat, amelyek azzal foglalkoznak, hogy a tanárok mentális jólléte hogyan hat a diákokra. Számba veszi a jóllét koncepciókat, különös tekintettel fordul a pozitív pszichológia értelmezési keretében született jóllét koncepciókhoz, illetve kitekint az érzelmek iskolai megjelenésére. Tárgyalja a pedagógusszemélyiség jellemzőinek összefüggéseit a pszichés jólléttel, továbbá kitér a pedagógusok mentális jóllétével foglalkozó hazai kutatásokra. Az önreflexió pedagógiai gyakorlatban való alkalmazásának a pszichés jólléttel való öszszefüggéseit a magyar eredményeken túl, egy nemzetközi példán keresztül is bemutatja.

\section{Jóllétkoncepciók, flow és optimizmus}

A WHO (1998) meghatározása szerint a mentális jóllét az az állapot, amelyben az egyén képes megküzdeni az őt ért átlagos mértékű napi stressz-szel, kibontakoztatni a képességeit, és eredményesen tevékenykedni a munkában és a közösség érdekében. Ryan és Deci (2001) összefoglaló pszichológiai egészség elméletet alkotott, az úgynevezett önmeghatározás elméletet (SDT, Self Determination Theory), amely három alapvető pszichológiai szükségletet ír le: a kompetencia, az autonómia és a valamihez való tartozás kielégítésének szükségleteit.

Mindazonáltal a jóllét fogalma nehezen definiálható. A fogalom értelmezésében különböző súllyal kerülnek elő az egyén életminőségét leíró objektív és szubjektív szempontok. Az objektíven megfigyelhető elemek az egyén anyagi, fizikai, szociális környezete, valamint az egészségügyi állapota. Ezek mellé az egyéni, szubjektív aspektusok társulnak jelesül, hogy az egyén hogyan tekint a környezetére, saját lehetőségeire, miként értékeli azt (Szántó et al., 2016).

A jóllét szubjektív megközelítését két nagy elmélet is leírja. A hedonisztikus szempontú értelmezés szerint a szubjektív jóllét állapotát az egyén életében a pozitív érzelmek és hangulatok gyakori megtapasztalása jelenti, amely mellett a negatív hatások megtapasztalásai ritkák. Mindezek eredményeként jön létre az élettel való elégedettség (Diener \& Lucas, 2000). A hedoniszti- 
kus jóllét felfogásból kiindulva Deci és Ryan (2000) szerint a jóllét egyfajta szubjektív boldogságérzet, amelyet az életünk eseményeinek - tetteink eredményei, céljaink elérése - pozitív értékelése által kapunk. E mellett az eudemonikus elmélet a pszichológiai jóllét milyenségét az emberek által betöltött szerepek és az önmegvalósítási igény közötti összefüggésben látja. Keyes és Ryff (1995) szerint az egyéni önmegvalósítás alapjait az autonómia, a személyiség kiteljesedése, az önelfogadás, az életcél, az önuralom és a pozitív emberi kapcsolatok jelentik.

A pszichológiai jóllét fogalomköréhez kötődik az életszemlélet milyensége, például a flow fogalma vagy az optimizmus skála. A flow vagy áramlatélmény Csíkszentmihályi (1997) elmélete szerint személyiségünk kiteljesedésének egyik fó eleme, amely során kedvelt tevékenységünk alatt komplex élményt élünk át, amely olyan koncentrált tudatosság, intenzív jelenlét érzetet ad, melyen keresztül boldogságszerű optimális élményt élhetünk át. Flow élmény során szinte „szárnyal a lelkünk”. Oláh az optimális fejlődéshez elengedhetetlennek tartja a kielégítő pszichoszomatikus status, a pszichológiai jóllét mellett a flow élmény gyakori átélését (Oláh, 2005).

A diszpozicionális optimizmus, mint személyiségjellemző alatt azt értjük, hogy a személyiség általános vonása a jó dolgok elvárása, amely stressz helyzetekben is megjelenik (Oláh, 2005). Ezt a személyiségjellemzőt különféle optimizmus skálákkal mérjük.

\section{Tanulási környezet: érzelmek az iskolában}

A konstruktivista pedagógia képviselői jelentős szerepet tulajdonítanak a tanulási környezetnek, ezen belül az érzelmek iskolai szerepének a tanítás-tanulás folyamatában. A konstruktivista megközelítéssel hozza összefüggésbe a klasszikus, humanisztikus pszichológia nevelést Cornelius-White (2007), aki a személyközpontú, rogersi értelemben vett tanácsadás jellegű nevelést helyezi a fókuszba. A tanulás- és a tanítás hatékonyságával összefüggésben a személyes kapcsolatok fontosságát hangsúlyozza, visszanyúlva a kapcsolatelméletekhez (Bolwby, 1969; Stern 1977). Cornelius-White kiemeli, hogy a kapcsolat kutatások figyelembe veszik a hosszantartó nexusok személyiségformáló hatásait.

Réthyné (2016) vizsgálja a pedagógus jólléte, valamint munkájának hatékonysága közötti összefüggést. Kifejti, hogy erős összefüggés mutatkozik a pedagógus elégedettsége, érzelmi kiegyensúlyozottsága, jólléte átélésére, boldogságra, örömre való készsége és a pedagógiai munkájának hatékonysága között. A tanárok jóllétének függvényében értelmezi a diákok szükségletorientált érzelmi fejlődését és -fejlesztését, tehát a pedagógusok jólléte pozitív kihatással van a diákok érzelmi fejlődésére, és nem kevesebbet állít, mint hogy a tanárok mentális egészsége közvetve még az osztálytermi agresszió és a spontán kirekesztődés ellen is hat (Réthyné, 2016). 


\section{Tanárok pszichés jólléte és a diákok iskolai teljesítményének összefüggései}

A bevezető során tárgyaltuk a pszichológiai jóllét definícióit, amelyek általában azonosak abban, hogy a pozitív kapcsolatok részei pszichés jóllétünknek. Mindez persze az iskola világában is érvényes.

Hattie (2008) nagyszabású metaanalízis módszertanú kutatása több mint 150, a diákokat ért hatást különböztet meg, amelyek befolyásolják a tanulás hatékonyságát. Számunkra is nagy jelentőségủek azok az eredményei, miszerint a pozitív tanári visszajelzések pozitív hatást jelentenek a diákok teljesítményére, önbizalmára, és saját teljesítményük önálló értékelésének lehetősége is fejlesztő hatású. E kutatás eredménye szerint annál, hogy mit tanít a pedagógus, sokkal fontosabb, hogy hogyan teszi ezt, és az a mód, ahogy gondolkodik a tanításról, önmaga szerepéről ebben a folyamatban. Kiderül belőle az is, hogy pozitív hatású a diákokra a tanárok munkájuk iránti elkötelezettsége, melyet közvetíteni és átadni is tudnak; a tanítás minősége; a tanulókkal való kapcsolatuk; a tanulók társkapcsolataiban rejlő motiváló erő. Ezek mind befolyásolják a tanulók önértékelését, valamint a feléjük irányuló elvárásokat. A motiváló tanár többet vár el, kifejezi, hogy a diák többet is ki tud hozni magából, és segíti őt ebben.

Hattie (2008) kutatása szerint a legerősebb pozitív hatása a diákok teljesítményére a kollektív tanári hatékonyság faktorának van, amely azt jelenti - nyilván egy hatékonyan dolgozó, közösséget építő, támogató vezetéssel a háttérben -, hogy a tanárok közössége osztja azt a szemléletet, miszerint a tantestület együttes erőfeszítései a diákok tanulására pozitív hatást tesznek (Hattie, 2008). Ennek a hatásnak a pszichológiai magyarázatához elég a jól ismert Pygmalion effektushoz visszanyúlnunk, vagyis a tanárok pozitív elvárásai pozitív attitüdökkel társulnak a diákok felé, és mindez valóban pozitív eredményeket teremt (Rosenthal, 1968). A kollektív hatékonyság légköre kedvezően hat a tanárok egyéni tehetségének kibontakozására is, amely a szakmai én kiteljesedését segíti, ennek pozitív megélése pedig az elköteleződést támogatja.

Az így kialakult munkahelyi klíma pozitív pszichológiai légkört eredményez, amely mind a diákokra, mind a pedagógusokra hat, hiszen pszichésen egészségesebb, a diákokhoz türelmesebb, elfogadóbb, pozitív attitüddel közeledni képes tanári attitüdöt, következésképpen kiegyensúlyozottabban teljesítő diákokat eredményez (Buda \& Péter-Szarka, 2015).

Cornelius-White (2007) kutatásában arra az eredményre jutott, hogy a pozitív tanár-diák kapcsolatok összefüggésben vannak az optimális, holisztikus tanulással. Rámutat arra a kétirányú összefüggésre, hogy a tanulói kooperáció és eredményesség éppúgy hatékonyabb pedagógiai munkát eredményez, mint ahogyan a hatékony tanári munka eredményessé teszi a tanulót. Mind a kognitív, mind az érzelmi, mind a szociális területeken összefüggést talált a tanárok rogersi értelemben vett személyközpontú megközelítése, és a 
diákokra tett pozitív hatás között. Mindez azért izgalmas, mert a humanisztikus pszichológia alapelvei a személyiség kibontakoztatását tüzik ki célul, pedagógiai irányzatuk ezen elgondolás iskolai adaptálása. Valójában a diákok pszichés jóllétét is fejleszti egyben, hiszen önmegvalósítási igényüket támogatja.

Az elemzések alapján elmondható, hogy szinte az összes személyközpontú terápiás elem iskolai alkalmazása (empátia, tisztelet, nondirektivitás, bátorítás a tanulásra és a gondolkodásra, a másság elfogadása) pozitívan hat a diákokra. Legerősebb hatásként a diákok aktivitására, azután kritikai gondolkodására, elégedettségére, teljesítményére matematikából, a lemorzsolódás megelőzésére, az önértékelésre, a nyelvi készségekre, motivációjukra, szociális kapcsolataira, IQ-ra, jegyeikre és -legkevésbé-, de azért hatott a tanórai zavaró magatartás csökkenésére is.

Ugyanakkor felmerülhet a kérdés, ki az a pedagógus, milyen az a pedagógus személyiség, aki hatékonyan alkalmazni képes a humanisztikus pedagógiai elemeket, vagy egyáltalán az érzelmek fejlesztésére alkalmas? Feltételezhetjük, hogy a pedagógusszemélyiségtől is függ, képes-e a feladatra, illetve attól is, milyen pszichés állapotban van aktuálisan.

\section{Pedagógus érzelmi állapot vizsgálatok - A kiégés kutatása hazánkban}

A tanulmány a pszichés jóllét témáját járja körül, felmerülhet a kérdés, hogy kerülnek bele mégis a kiégés kutatások. A pozitív pszichológia az egészség fogalmának új megközelítését hozta, előtte főleg a betegség hiányát tekintették egészségnek a pszichológia művelöi. Ezért jelen tanulmány részben a kronológiai sorrend miatt a jóllét hiánya felől közelít, amikor a korai kutatásokat bemutatja, részben azért is, mert a kiégés, a mentális betegség vizsgálata az érem másik oldalát mutatja meg, így kaphatunk teljesebb képet a tanári mentálhigiéné aspektusairól.

A hazai neveléstudományi vizsgálatokban, a klinikai pszichológia felől közelítve, már a '90-es évektől felbukkan különböző aspektusokból a pedagógusok kiégésének vizsgálata. A vizsgálatokban legtöbbször a Maslach Burnout Inventory (MBI) tesztet használták a kutatók, ami a kiégés kutatás valid vizsgálati eszköze.

Petróczi és munkatársai (1999) ötszáz pedagógus bevonásával végzett felmérésükben azt találták a mentálhigiénés állapottal összefüggésben, hogy a pedagógusok 62\%-a elégedetlen anyagi helyzetével és $26 \%$-uk elégedetlen saját életével. Ónody (2001) szerint a pedagógusok között uralkodó teljesítmény- és önfeláldozás-orientált világban a kudarc nem vállalható. A kiégés szindróma tagadásában és elutasításában találja kutatási-, kezelési-, megelőzési nehézségét az érintettek részéről.

Fontos kutatások a témában Paksi és Schmidt (2006), Paksi és munkatársai (2015), kutatásai, akik áttekintették a pedagógusok kiégésének jellemzőit. 
Az első vizsgálatban a szervezeti szempontok emelkedtek ki, míg a majd tíz évvel későbbi vizsgálatban Paksi és munkatársai a kiégés mellett a személyiségdimenzió jellemzőit tekintették át a Big Five kérdőív (McCrae \& Costa, 1987) segítségével. Az ötfaktoros modell a személyiség fö dimenzióit öt, egymástól jól elkülönült személyiség faktorként látja, melyek a következők: I. Neuroticitás, II. Extraverzió, III. Nyitottság a tapasztalatra, IV. Barátságosság, valamint V. Lelkiismeretesség (Mirnics, 2006).

A kiégéssel összefüggésben vizsgált két fő témacsoport a környezet és a személyiségjellemzők hatása. Paksi és Schmidt (2006) első vizsgálatának eredményei azt mutatták, hogy elsősorban az iskolai szervezet belső világának milyensége, az iskola légköre, hangulata, az iskolán belüli viszonyok vannak összefüggésben a pedagógusok mentális jellemzőivel, kiégésével. A vizsgálat megállapítja, hogy a pedagógustársadalomnak a tanár-diák viszonyok szempontjából releváns mentális jellemzői a felnőtt népesség átlagához képest kedvezőek.

Több hazai kutatás vizsgálta az empátia és a kiégés összefüggéseit. Szebeni (2010) az MBI (Maslach Burnout Inventory) kérdőív használatával megmutatta, pedagógusok esetében az egyéni teljesítmény csökkenése a legerősebb kiégési mutató. Eredményei szerint, az egyéni teljesítménycsökkenés értéke az életkor előrehaladtával is növekszik. Szebeni kutatása hosszú távon arra irányul, hogy az oktatás sikerességét befolyásoló pedagógusszemélyiség-elvárások tudatos képzési modell segítségével jelenjenek meg a pedagógusképzésben. Megvizsgálta, milyen összefüggés mutatkozik a teljesítméncsökkenés és a tevékenységtípus között. Elgondolkodtató, hogy a kompetenciaprogramban dolgozó pedagógusok teljesítménycsökkenése ami a kiégés mutatója -, szignifiánsan magasabb volt a vizsgált mintában. Az összefüggést, valószínủleg a kompetencia alapú oktatásban résztvevő pedagógusok empátiás odafordulásának minősége okozhatja, amikor az empátiás odafordulás során a saját énjük védelmére kevesebb energiát fordítanak.

Az eredményt alátámasztja, hogy azok a pedagógusok, akik nem vettek részt esetmegbeszélő, illetve olyan csoportokban, ahol önreflektív tevékenységet folytattak, jelentősen nagyobb distresszt élnek át munkájuk során (Kolosai \& Bognár, 2007). Distressz esetén a pedagógus nem a tanulók pozitív megküzdésmódjaival empatizál, hanem a megküzdés nehézségeivel. Ez hosszú távon elkerülő magatartáshoz, valamint kiégéshez vezet (Davis, 1994). Az önreflexiót facilitáló csoportban résztvevő pedagógusok érzelmileg megterhelő helyzetben nagyobb fokú empátiás perspektívafelvételre voltak képesek, illetve érzékenységükkel a tanulók felé tudtak fordulni (Kolosai \& Bognár, 2007).

Holecz és Molnár (2014) a pedagógusok jóllétét befolyásoló tényezőket nézték meg, melyben rákérdeztek az általános és munka-boldogság szintre, a munkaelégedettségre, és a flow-képességre. A tanulmány boldogságra vonatkozó eredményként arról számol be, hogy a teljes mintára vonatkoztatva a pedagógusok boldogságszint átlaga és a munkahelyi boldogságszint átlaga 
szinte azonos, illetve az is kiderült, hogy összességében a pedagógusok körében mérhető boldogságszint közel azonos a magyarországi összpopulációs boldogság szinttel is.

Paksi és munkatársai (2015) a pedagógusok pályamotivációját vizsgálva, a pedagógusok kiégés jellemzőit is áttekintették. A demográfiai adatokat elemezve azt találták, hogy a vizsgálatban a kiégés egyik alskálája sem mutatott kapcsolatot az életkorral, a pedagóguspályán töltött évek számával, a tudományos fokozat meglétével, illetve azzal, hogy a képesítésének megfelelö munkakörben dolgozik-e a vizsgált pedagógus. Ugyanakkor a demográfiai változók egyéb tételei hoztak összefüggést: több képzettséggel kapcsolatos indikátor esetén alacsonyabb kiégési értékeket jeleztek. Általában a nyelvtudás, a továbbképzések óraszáma, egy-egy alskála esetében pedig a képzettségi szint és a tanulmányi eredmény pozitív együttjárást mutatott a mentális egészséggel. Paksi (2015) szignifikáns kapcsolatot talált a munkával összefüggő individuális jellemzőkkel, valamint a tanított tárgy típusával. Az öszszefüggés iránya a természettudományi tárgyat (is) tanítók nagyobb kiégési kockázatát jelzi.

Antalka (2015) a kiégés okait csoportosította: fáradtság, szerepkonfliktus, szervezeti és interperszonális kapcsolati konfliktusok, a self jóllétének felborulása, stressz, Helfer- szindróma ${ }^{1}$ és elvárások mentén. Szerinte a szindróma jelenléte és különböző mértékű érintettsége egyénenként változik, és az egyéni teherbírás szabályozza, hogy a pedagógus a kiégésben érintetté válik-e.

Szabó és Jagodics (2016) kutatásukban az iskolatípusok között találtak különbséget a tanári kiégést vizsgálva. Tanulmányukban rámutattak a szakközépiskolai tanárok körében mutatkozó magasabb burnout jelenség meglétére.

A pedagógusok munkaboldogását kutatva Kun-Szabó (2017) arra az eredményre jutott, hogy a pedagógusok $87 \%$-a legalább átlagos mértékben boldognak tartja magát a munkájában. A munkahelyen megélt boldogságot nagyon sok olyan tényező befolyásolhatja, amelyek egy része nem közvetlenül a munkához kapcsolódó tényező. Ilyenek például a pedagógus neme, a gyerekeinek száma, az átélt munkastressz mértéke, az általános egészségi állapot. Mindebből az is látszik, hogy a személyes én és a szakmai én erős kölcsönhatásban létezik.

Szabó, Litke és Jagodics (2018) az óvodapedagógusok körében tapasztalható kiégést a munkaértékek tükrében vizsgálta. Kutatásukban a kiégés alacsony mutatóit találták hasonlóan a korábbi pedagógus burnout vizsgálatokhoz. Eredményeik szerint a kiégést veszélyeztető tényezőként a megértő és demokratikus vezető hiánya, a csökkent önmegvalósítás élmény és a változatosság értékének alacsony megjelenése jelenik meg.

\footnotetext{
${ }^{1}$ W. Schmidbauer pszichoanalitikus által leírt jelenség a Helfer/ segítö/ szindróma” (1977). Azok a segítő foglalkozásúak tekinthetőek szindrómás segítőknek, akik bizonytalan önértékelésüket igyekeznek kompenzálni a segítés túlhajszolásával, és akik számára a segítés sokszor önkárosító, a magánéletüket romboló hatású.
} 
Borbáth (m.a.) pedagógusnők mentálhigiénés állapotát vizsgáló kutatásában kiégést is vizsgál és női személyiség feltérképezésére is kísérletet tesz. Ugyanakkor ez a vizsgálat kitekint a kiégés mellett a mentális egészségre vonatkozó életszemlélet vizsgálatára, és a női személyiség tipológia mellett a szakmai személyiség jellemzőinek felmérésére. A demográfiai adatok elemzésében találunk hasonló tendenciákat a két vizsgálatban. Borbáth (m.a.) felmérésében, hasonlóan Paksi és Schmidt (2006) kutatási eredményeihez, az életkor emelkedésével nő a kiégés mértéke. Borbáth (m.a.) kutatásában elsősorban a pedagógusnők mentálhigiénés állapotára fókuszált. Eredményei szerint a vizsgált pedagógusnők érzelmileg kimerültek, gyakran nem is érzik magukat elég hatékonynak, feltehetően a nagyfokú érzelmi terhelés okozta kimerülés, és az ezzel járó kevésbé hatékonynak megélt nehéz helyzetek, konfliktusok okozzák ezt. A vizsgálatból a kiégésre vonatkozóan az derült ki, hogy a pedagógusnők számára valós veszélyt a burnout felé vezető úton az érzelmi kimerülés és a személyes hatékonyság csökkenésének megélése jelenti leginkább.

\section{A pozitív pszichológia aspektusai a pedagógusok pszichés jóllétével összefüggésben}

A pozitív pszichológiai témájú kutatások között találunk elemzéseket, melyek a pedagógusok jóllétének pozitív oldalával, előnyeivel, pozitív hatásaival foglalkoznak. Bricheno, Brown és Lubansky (2009, idézi Kun-Szabó, 2017) kimutatták, hogy a tanárok jólléte hatással van a tanulók eredményeire. Briner és Dewberry (2007, idézi Kun-Szabó, 2017) reprezentatív vizsgálatuk során általános és középiskolák alkalmazottainak jóllétét vizsgálták. A felmérés eredményeként erős pozitív együttjárást kaptak az ott dolgozók jólléte és a diákok eredményei között.

Más tanulmány pozitív pszichológiai kontextusban a tanulók optimális iskolai terhelésével kapcsolatban hangsúlyozza a pedagógus szerepét, hiszen neki kell úgy alakítani a követelményeket és a terhelés szintjét, hogy azzal tartós flow állapotba hozza a tanulókat, mert ő ismeri a gyerekek erősségeit, amelyek mentén, az optimális élményt átélve, teljesíteni tudják az elvárásokat (Oláh, 2011). Erre alapozva beszélhetünk pozitív pedagógiáról is, amely a pozitív pszichológia megközelítésének gyakorlati alkalmazási lehetőségeit keresi az iskolában (Hamvai \& Pikó, 2008).

A jóllét a munkahelyi elégedettség és elkötelezettség fontos eleme, mert a nem megfelelő jóllét elégedetlenséghez és akár a munka vagy a pálya elhagyásához is vezethet (Singh \& Billingsley, 1996). A munka vagy pályaelhagyás hátterében, akkor is ha pályakezdő tanárokról van szó, gyakran találjuk a kiégést (Goddard \& O’Brien, 2006).

Hazai pedagógus minta felmérését végezte Nagy és Gyurkovics (2016). Optimizmus vizsgálatukban azt az eredményt kapták, hogy a jóllét szintje az optimizmussal szoros összefüggésben van, a Big Five dimenzióktól (McCrae \& Costa, 1987) függetlenül. 
Ugyanakkor Borbáth (m.a.) vizsgálata további aspektusokat tárgyal. A pedagógusnők mentálhigiénés állapotát vizsgáló felmérésben hangsúlyt kap a kiégés vizsgálata mellett a pszichés egészséghez köthető fogalmak tanórai megjelenésének gyakorisága a tanár részéről. Ilyenek a pszichés jóllét, az áramlatélmény megélésének képessége, a pozitív életszemlélet vagy optimizmus fogalma, illetve a pedagógiai önreflexió gyakorlata is. Az összehasonlító statisztikai elemzések a kiégés és az életszemlélet milyensége között azt az összefüggést mutatják, hogy a kiégés által veszélyeztetettek nem feltétlenül realisták, de a realista/kevésbé optimista életszemléletűeket valószínűbben fenyegeti a kiégés. Mondhatjuk, hogy az optimista életszemlélet a kiégés minden fö formájával szemben védelmet nyújt. A vizsgálatban a flow tanórai megélésének képessége, mint legerősebb mentálhigiénés védőfaktor jelent meg (Borbáth, m.a.). Hasonló eredményre jutott Holecz és Molnár (2014) akik kapcsolatot találtak a pedagógusok munkavégzés során alkalmazott erényei és munkavégzés során megélt áramlatélményük között.

Továbbá kiderült az is Borbáth (m.a.) felméréséből, hogy a pszichológiai témák, és az önismeret iránti nyitottság együtt jár az alacsonyabb kiégési veszélyeztetettséggel. Paksi és munkatársai (2015) vizsgálatához hasonlóan összefüggést talált a szakterület és a kiégés szintje között. Ugyanakkor különbség, hogy míg Paksi és munkatársai (2015) vizsgálatában a természettudmányokat tanítók, többnyire férfiak a kiégés által veszélyeztetettek, addig Borbáth (m.a.) vizsgálatában, aki csak a női pedagógusokra fókuszált, a nyelveket tanítók mutatkoztak a leginkább kiégés-veszélyeztettnek a vizsgálati mintában. A terhelés egyenetlensége magyarázhatja a szakterületek között megjelenő különbségeket, továbbá magyarázat lehet, hogy a Borbáth-féle mintában alacsony elemszámmal jelentek meg a természettudományokat tanítók, akik nagyobb arányban férfiak. Borbáth (m.a.) vizsgálatában azt látjuk, hogy az óvónőket és a nyelvszakos tanárokat összehasonlítva szignifikánsan magasabb szintű az érzelmi kimerülés a nyelvszakosoknál, továbbá az adatok szerint a nyelvszakosok erősebben válnak elszemélytelenedetté a müvészettanároknál. Borbáthnál (m.a.) eredményei szerint, az énhatékonyság-érzés csökkenése magasabb szintű a tanítóknál, mint az óvónőknél, ami szintén a kiégés veszély egyik mutatója lehet (Borbáth, m.a.). Ezek a hazai, pedagógusok mentálhigiénés állapotát feltérképező vizsgálatok támpontokat nyújtanak abban, hogy növekedjen a rálátásunk a pedagógusok lelki egészségének milyenségéről, illetve ezen mentálhigiénés állapotuk által eredményezett hatásokról.

\section{A pedagógusszemélyiség mint értelmezési keret a pedagógusok pszichés jóllétével összefüggésben}

A pedagógus mentálhigiénés állapotát, jóllétét a szakirodalom két oldalról vizsgálja, a szervezeti tényezők felől, elsősorban az iskolai klímát vizsgálva, és a pedagógus személyiség jellemzőinek vizsgálata felől. Jelen tanulmány a peda- 
gógus személyiség megragadására vonatkozó kurrens személyiség elméletek és vizsgálatok tanulságait összegzi. Az interdiszciplináris témafelvetés, a pedagógus személyisége újra a neveléstudományi kutatások fókuszába került (Göncz, 2017). Személyiség definició számtalan létezik, mégis amiben a legtöbb szerző egyetért az, hogy "strukturális szempontból a személyiséget az alkotóelemei írják le: temperamentuma, karaktere és az intelligenciája" (Döme, 2006, p. 17).

A pedagógusok esetében az intelligencia alkotóelem nem releváns, hiszen a pálya kritériuma miatt a felsőfokú végzettség elvárás, amely közelítő becslésekre ad alapot a tárgyalt populáció intelligencia övezetéről.

A temperamentumról Cloninger pszichobiológiai modelljét vesszük alapul, amely szerint a temperamentumot hangulatok és szokások alapján írhatjuk le, mintegy automatikus válaszrekciók sajátos mintázataként felfogva, amelyet érzelmi hatásokat kiváltó ingerek okoznak. Ezen temperamentumjellemzők mentén alakul ki szerinte a karakter, amely tudatosan kiépített személyiségjegyek bizonyos konstellációját jelenti (Holecz, 2010).

Bár az ókorban megkezdődött a személyiség leírása a temperamentum típusok meghatározásával, a mai személyiségpszichológia ezzel szemben inkább vonásokat mér. Míg a típusok merev határokkal rendelkező, nem folytonos kategóriák, a vonásokat folytonos, dimenzionális személyiségjegyekként írhatjuk le. Legtöbben úgy vélik, a viselkedés mutatja meg közvetlenül, hogy ki milyen személyiség, így a vonáselmélet hívei a személyiségbeli eltéréseken alapulva különbözőségeket feltételeznek az emberek viselkedésében. A különböző átfogó személyiségjegyek konkrét helyzetekben megfigyelhető viselkedés mozzanatokból állnak.

További egyetértés az elméletalkotók között, hogy a személyiség rétegződik, hierarchiával rendelkezik. Felmerül a kérdés, az emberek többségénél hasonló-e a hierarchia és egyáltalán a személyiség struktúrája? A nomotetikus szemlélet igenlő választ ad (például Big Five elmélet, McCrae \& Costa, 1987), az idiografikus szemlélet ezzel ellentétben azt feltételezi, hogy a tulajdonságoknak minden embernél részint egyedi jellemzői vannak, és akár egy-egy embernek egyedi vonásai, tulajdonságai, tulajdonságmintázatai is lehetnek (Mirnics, 2006). Tanulmányunk a teljesség igénye nélkül, a pedagógus személyiségjellemzők legújabb kutatási eredményeit tekinti át a pszichés jóllét kérdéskörében.

A pedagógusszemélyiség vizsgálat relevanciáját támasztják alá azok az izgalmas eredmények, amelyekre Rhuston és munkatársai (2007, idézi Suplicz, 2012) kutatásaik során bukkantak. Kimutatták a Myers-Briggs értékelő skála segítségével, hogy milyen a pályán található leggyakoribb pedagógus karakter, továbbá azt is, hogy milyen a legjobb pedagógusszemélyiség. Érdemes megjegyezni, hogy a kettő nem esik egybe. A skála dimenziói: Extraverzió (E) - introverzió (I), ítéletalkotás (judging, J) - észlelés (perception, P), érzékelés (sensing, S) - intuíció (intuition, N), gondolkodás (thinking, T) - érzés (feeling, F). Az általános iskolai tanítók között az Myers-Briggs kérdőív alapján definiált (ISFJ) introvertált érzékelő-érző-ítélkező típust találták leggyakoribbnak, miközben 
a középiskolai tanárok között az érzékelő-érző-gondolkodó típusok voltak jelen leginkább. Ugyanakkor a legjobbnak tartott középiskolai tanár típusnak -szintén a Myers-Briggs kérdőív alapján-az (ENFP) extravertált - intuitív érző - észlelő, és az (ENTP) extravertált - intuitív - gondolkodó - észlelő típus emelkedett ki (Rhuston, 2007, idézi Suplicz, 2012).

A személyiség megragadására a tipológia, a karakterként való értelmezés is egy járható út, ugyanakkor ez az aspektus jellegéből adódóan statikus megközelítéseket tesz lehetővé. Miközben a személyiség állandó változása, összefüggésrendszerekben való különböző müködése dinamikus jellemzőket is sejtet. Ezt a dinamizmust jeleníti meg személyiség fogalmában Cornelius-White (2007). Szerinte a nők, férfiak és a gyerekek is komplex kapcsolati hálózatokban élnek, ezeken a viszonylatokon keresztül értelmezhető az én. Vagyis a személyiséget értelmezhetjük kapcsolatai hálózatán keresztül is.

Mindez érvényes lehet a pedagógusokra is? Igen is, meg nem is. A pedagógusra többféle értelemben tekinthetünk, legalább két fö aspektusát vizsgálhatjuk. Először is a pedagógus, mint személy, mint egyén, mint önálló entitás van jelen az iskolában és éli a mindennapjait. A hivatás személyiség, mint olyan a tanári lét másik aspektusa. A pedagógusszemélyiség elkerülhetetlenül kifejleszt egy szakmai ént, hiszen munka közben önmagát használja, mint munkaeszközt. Ha ez a hivatás, vagy szakmai személyiség nem egy tudatos, átgondolt, önismereten alapuló személyiségrész, akkor valójában nem több, mint egy álca, maszk, amibe belebújik a pedagógus (Borbáth \& Horváth. H., m.a.). Ha viszont így van, hitelességét veszti, az érzelmi kapcsolata a diákokkal sérül. Ez pedig a munkája hatékonyságát is befolyásolja, hiszen kutatók állítják, a gyerekek nem tanulnak attól a pedagógustól, akit nem szeretnek (Aspy \& Roebuck, 1977).

Szebeni (2010) mestertanár képzésben résztvevők karakterjellemzőit vizsgálta. Vizsgálatában számot vetett azzal is, hogy a pedagógus vizsgálat adatai torzítanak, a magas megfelelési igény szándékoltan vagy tudattalanul szerepet játszik a kérdőívek eredményeiben. A Big Five kérdőívet (McCrae \& Costa, 1987) használva azt az eredményt kapta, hogy az energia/dinamizmus, barátságosság, lelkiismeretesség, érzelmi stabilitás (neuroticitás), nyitottság kategóriákban, a nyitottság mentén térnek el legerőteljesebben a pedagógusok az átlag populációtól, jelentősen kevésbé nyitottnak bizonyulva. Ugyanakkor érzelmi stabilitása a vizsgált pedagógus mintának megfelelö, hiszen csak 43\%-uk ért el átlagos, vagy az alatti értéket a neuroticitás skálán. Az életkor előrehaladtával jobbak a pedagógusok a nyitottságban, barátságosságban, érzelmi stabilitásban, ugyanakkor a fiatalabbak a lelkiismeretességben, és az energiában értek el magasabb értékeket. Jellemzően külső kontrollos attitüdöt, illetve az empátia magas szintjét találta a pedagógus jelölteknél, amely azonban nem járt együtt az énre irányuló empátiás attitűddel, ami a segítségnyújtás esetenkénti visszautasítását jelenti (Szebeni, 2010).

Paksi és munkatársai (2015) a lelki egészség személyiség dimenzionális aspektusait vizsgálják a pedagógus pályamotivációval összefüggésben. A Szebeni-féle kutatástól eltérően Paksi és munkatársai nem a pedagógusok 
és az átlag populáció közötti eltéréseket vizsgálják, hanem a pedagógusok lelki egészségére ható tényezők közötti összefüggéseket keresik. A személyiségdimenziók feltérképezésére szintén a Big Five kérdőívet használják. Eredményeik szerint legmagasabb móduszt a Lelkiismeretesség faktor adta a vizsgált mintában, legalacsonyabbat a Neuroticitás faktor. Mindkét eredmény üdvözlendő a pedagóguspályán tevékenykedők körében.

Párhuzamosan a pedagógusok lelki egészségét vizsgáló kutatások növekvő számával, világszerte reneszánszukat élik a humanisztikus elméletek. Mind a nevelés, mind a pszichológia terét átfogó postumus Rogers mü (2013) a pedagógusszemélyiséget elemzi. Rogers felidézi Aspy and Roebuck 1977-es fontos terepkutatását, amelynek során a kutatók azt találták, hogy a legsikeresebb tanárok a leginkább személyközpontúak is egyben. Nem elhanyagolható a másik fontos összefüggés sem, miszerint a legsikeresebb tanárok munkája magasabb tanulói teljesítménnyel is párosul (Aspy \& Roebuck, 1977 idézi Rogers et al., 2013).

A szerzőcsoport megállapítja, hogy a kiegyensúlyozott, pozitív tanár-diák kapcsolat a sikeresség záloga. Ennek hátterében azonban egy jól működő pedagógusszemélyiséget kell feltételeznünk (Rogers et al., 2013). Mindezek alapján jól érzékelhető, hogy a pedagóguszemélyiség kutatás irányzata számos érdekes, új neveléstudományi eredménnyel kecsegtet, amelyek számos ponton összefügghetnek a pedagógusok pszichés jóllétével. Miközben a pedagógusok vizsgálata nemcsak a személyiség, hanem a müködésmód, ezen belül is az önreflexió gyakorlása tekintetében is hozhat összefüggéseket a pszichés jóllétükkel kapcsolatosan.

\section{Az önreflexió összefüggései a pedagógus pszichés jóllétével - A finn példa}

A reflektív gondolkodás tudatos elemzést jelent, az ezen alapuló tanítás tudatos elemző gyakorlatot. Kétféle iránya lehet a pedagógiai reflektív gondolkodásnak, az egyik a tanárok és a tanulók, csoportok történéseire irányul, illetve saját személyére, saját elképzeléseire és tevékenységére, ez utóbbit önreflexióként említjük. A nevelés interaktív jellegére mutat rá Horváth Attila (1996), aki a folyamat során a kölcsönösségre és az azt követő reflexió jelentőségére hívja fel a figyelmet. Szerinte a nevelés sikere azon múlik, hogy a folyamat résztvevői mennyire tudnak egymás elvárásaihoz igazodni, egyezségre jutni, reflektív kommunikációt folytatni (Horváth, 1996). Mindebből az is következik, hogy a pedagógusok egyik alapvető készsége az önreflexió. Tókos (2005) „új arcú” reflektív pedagógusként jellemzi a saját személyisége működését és a diákokét is folyamatosan felmérni törekvő pedagógust. A reflexió készségszintű használata komplex tudatosságot jelent a tanulás- és a tanítás folyamatának aspektusaira, igazából a rogersi értelemben vett jelenlétet mutatja, ilyen módon az autonóm személy müködését írja le. Az autonóm müködésmód feltételezi az önmegvalósítás képességét, vagyis visszahat 
a pedagógus pszichés jóllétére. Az autonóm személyként működő pedagógus pedig minta az érzelmeik szabályozását tanuló diákok számára.

Kimondható, hogy a reflektivitást alkalmazó pedagógus egy teljesebb mesterségbeli tudás birtokosa (Sallai, 2004). Borbáth (m.a.) már említett vizsgálatában az önreflektív müködésmód és a kiégés szintjének összevetése azt az eredményt hozta, hogy a pedagógiai tudatosság, melynek egyik eleme az önreflektív viselkedés, mentálhigiénés védőfaktorként jelenik meg.

A reflektív pedagógus személyiség és működésmód további gyakorlati igazolását mutatja a tény, hogy napjaink európai oktatási sikermodelljét jelentő finn pedagógusképzés nagy hangsúlyt helyez a pedagógus saját szakmai énjének, - identitásának formálására. A finn modell „saját pedagóguskép” kialakítását ösztönzi, amelyben hangsúlyt kap a kutatómunka is (Kálmán, 2008).

A finn pedagógusképzésben központi szerepet tölt be a tanári identitás fejlődésének támogatása. Ezt erősíti a tanítás és a kutatás összekapcsolása, amivel már az egyetemi évek alatt a szakmai tudatosságot, szakmai ént fejleszti. Ezt szolgálják a finn tanárképzés önreflexióra nevelő gyakorlatai is (Kálmán, 2008).

A nevelés interaktív, egymásra ható jellegét ismerve kijelenthető, hogy a kiegyensúlyozottként jellemezhető finn iskolai klíma feltételezi a pszichés jóllét meglétét és folyamatos ápolását a pedagógusok részéről az iskolákban (Kálmán, 2008).

Nem emeltük ki külön, mert témánkhoz nem igazán releváns, de nyilván segíti a megújulást és a pszichés well-beinget, hogy az adminisztratív terhek sem túl nagyok a finn oktatási rendszerben a tanárok vállán, miközben a pedagógusok elismertek, és a tanítás a jól kereső professziók közé tartozik.

Jelen tanulmány számára releváns jellemzője a finn tanárképzésnek, hogy a folyamat során a hallgatók nem csak a tanári hivatást, mint funkciót ismerik meg, hanem személyiségük is jelentősen átalakul, hiszen az önismeretre, aktív tanulásra és kutatásra épül a képzési folyamat (Hercz, 2008). Láthatjuk, hogy a sikeresen működő pedagógusképzési modell jellemzői a kutatásközpontú szemlélet, amelyet megtámogat az önismereti tudás (Hercz, 2008), illetve az ezekre alapozott saját pedagógus identitás kialakítása az önreflexiós készség. Mindezekkel a képzett pedagógusok nagyfokú tudatosságát formálják, amely a kiegyensúlyozott pedagógus hivatásszemélyiség lényegi része is egyben. A pedagógusképzés ismeretében érthetjük meg igazán, hogy alapozzák meg a pedagógusszemélyiség fejlesztésével az általános kiegyensúlyozottságot, és harmonikus iskolai légkört.

\section{Összegzés}

A tanulmány felhívja a figyelmet az iskolai környezet egyik lényeges aspektusára, az érzelmek szerepére. Az iskola fó aktorai, a pedagógusok és a diákok minden kognitív cselekedetét érzelmek szövik át és hatnak rájuk. Ez a jelenség létezik az első iskolák megjelenése óta, az oktatás-kutatók figyelme 
mégis csak az utóbbi időkben terelődött az érzelmekre, amióta a pszichológia bebizonyította, hogy a diákok érzelmi állapota befolyásolja tanulásuk hatékonyságát (Jerusalem \& Pekrun, 1999). Azután lassanként arra is fény derült, elsősorban Hattie (2008) és Cornelius-White (2007) kutatásai nyomán, hogy a pedagógusok pozitív érzelmei hatnak a diákok érzelmeire, ez által teljesítményüket is pozitívan befolyásolják (Hattie, 2008).

A pedagógusok negatív érzelmi állapota már a 90-es évektől foglalkoztatja a hazai kutatókat. A kiégés vizsgálatok igyekeznek feltárni a kiégés mértékét, és az okokat. Az okokat külső, intézményi, szervezeti, iskolai klímára visszavezethetően (Paksi, 2006; Antalka 2015, Szabó \& Jagodics 2016, Szabó et al., 2018), a személyiségdimenziókat figyelembe véve (Paksi et al., 2015), illetve az önreflexiót facilitáló pedagógusképzéssel összefüggésben egyaránt keresnek (Kolosai \& Bognár, 2007).

A téma iránti érdeklődést mutatja, hogy differenciálódtak a pedagógusok mentálhigiénés állapotának vizsgálatát célzó felmérések, és releváns eredményeket hoztak a pedagógusok szakmai és érzelmi életének háttér összefüggéseiről (Holecz \& Molnár, 2014). A kiégés fókuszú kutatások mellett megjelentek a tanárokat a pszichés egészség szempontjából tekintő elemzések (Oláh, 2011; Hamvai \& Pikó, 2008), vizsgálódások is (Nagy \& Gyurkovics, 2016). Mindeközben a diákokra tett hatásuk miatt fontossá vált a tanári személyiség jellemzők kutatása és a figyelem a tanári személyiség dimenzionális sajátosságaira terelődött (Rhuston, 2007; Szebeni, 2010).

Borbáth (m.a.) pedagógusnő kutatása a kiégés és a pszichés jóllét vizsgálata mellett ráirányította a figyelmet a szakmai és személyes én kimunkáltságának jellemzőire, amelyek feltevése szerint szintén fontos faktorai a tanárok mentális egészségének. Hiszen rogersi értelemben az egyénnek azért, hogy összes tapasztalata tudatosítására képes, integrált személlyé válhasson a rogersi értelemben, folyamatosan dolgoznia szükséges önmagán (Gyöngyösiné, 2007). Másik paradigma rendszerben értelmezve ugyanezt a gondolatot: az egyéni életutat beteljesítő eudaimonikus, pszichológiai jóllét fogalma magába foglalja az önmegvalósítási igényét az egyénnek, beleértve természetesen a pedagógusokat is. Feltételezhető, hogy ez az igény megjelenik a hivatás szerepében és személyes életében egyaránt.

Fontos következtetés még, miszerint a pszichológiai jóllét magában foglalja a távolabbi célok elérésére, az önkiteljesítésre való törekvést. Ennek a meglétére jó fokmérő lehet, a magasabb szintre emelt képességek eredőjeként elért áramlat élmény megélésére való képesség (Gyarmathy, 2019), amelyet Borbáth (m.a.) erőteljes mentálhigiénés védőfaktorként talált a pedagógusnők körében végzett mentálhigiénés állapotot felmérő vizsgálatában.

Az elméleti alapvetések gyakorlati támaszaként jelenik meg az írásban korunk legsikeresebb, követendő példát adó finn tanárképzés modellje. Számunkra ebből az az aspektus a lényeges, hogy az önreflektív pedagógust, mint állandóan fejlődő, saját munkájára reflektáló, ily módon a szakmai személyiségét állandóan építő egyént követendő mintának tekintjük, és könnyü 
belátni, hogy a finn modellü tanárképzésben - az alapelvként értelmezett szakmai személyiség tudatos kialakítása is megvalósul. Hiszen nem (csak) elméleti szinten jelenik meg a képzésben az önismeret, a szakmai személyiség, mint téma, hanem konkrét pedagógiai cselekmény ${ }^{2}$ részeként alakulhat ki.

Érdemes feltenni magunknak a kérdést, hogy Magyarországon a pedagógusképzésben ezek a szempontok, komplex szemlélet jelen van-e, és ha igen, hol tartunk ebben a szemlélet kialakítási, szemléletváltási folyamatban? Mindezzel azért is fontos szembenéznünk, mert, ahogy körvonalaztuk fentebb, a tudatosság a pszichés jóllétet segíti, és tudjuk, hogy pedagógusok pszichés jólléte erősen befolyásolja a diákok jóllétét is az iskola világában. Vagyis mindenki jólléte a tét.

\section{Irodalom}

Antalka, Á. (2015). A tanári kiégés feltérképezése Kovászna megye középiskolai tanárainak körében. Doktori disszertáció, ELTE PPK Neveléstudományi Doktori Iskola.

Aspy, D. N., \& Roebuck, F. N. (1977). Kids don't learn from people they don't like. Human Resource Development Press.

Borbáth, K. (m.a.). Pedagógusnők mentálhigiénés állapotfelmérése különös tekintettel szakmai és személyes identitás jellemzőikre. In Sokszinü pedagógia. ELTE TÓK.

Borbáth, K., \& Horváth, H.A. (m.a.). Érzelmekaz oktatás világában. Neveléstudomány.

Bowlby, J. (1969). Attachment and Loss, Vol. 1: Attachment. Attachment and Loss. New York: Basic Books.

Buda, M., \& Péter-Szarka, Sz. (2015). A kreatív klíma. Iskolakultúra, 25(9), 3-17. https://doi.org/10.17543/ISKKULT.2015.9.3

Cornelius-White, J. (2013). Interdisciplinary Handbook of the Person-Centered Approach: Research and Theory. Springer. https://doi.org/10.1007/978-1-46147141-7

Cornelius-White, J. (2007). Learner-Centered Teacher-Student Relationships Are Effective: A Meta-Analysis. Review of Educational Research, 77(1), 113-143. https://doi.org/10.3102/003465430298563

Csíkszentmihályi, M. (2018/1997). Flow - Az áramlat. Akadémiai Kiadó.

Diener, E., \& Lucas, R.E.(2000). Explaining Differences in Societal Levels of Happiness: Relative Standards, Need Fulfilment, Culture, and Evaluati- onTheory. Journal of Happiness Studies, 1(1), 41-78. https://doi.org/10.1023/A:1010076127199

D. Szabó M., \& Pusztai G., (2016). Az Egészségügyi Világszervezet öttételes jóllét kérdőívének vizsgálata a Semmelweis Egyetem elsőéves hallgatóinak körében. Orvosi Hetilap, 157(44), 1762-1768. https://doi.org/10.1556/650.2016.30572

${ }^{2}$ Pedagógiai cselekmény a finn tanárképzésben a kötelező hallgatói kutatómunka. 
Döme, L. (2006). Személyiségzavarok. Filum Kiadó.

Falus, I. (2002). A tanuló tanár. Iskolakultúra, 6(7), 76-80.

Goddard, R., O’Brien, P., \& Goddard, M. (2006). Work Environment Predictors of Beginning Teacher Burnout. British Educational Research Journal, 32(6), 857-874. https://doi.org/10.1080/01411920600989511

Göncz, L. (2017). Teachers' personality: a review of psychological research and guidelines for a more comprehensive theory in educational psychology. Open Review of Educational Research, 4(1), 75-95. https://doi.org/10.1080/23265507 .2017.1339572

Gyarmathy, É. (2019). Pszichomeditáció. Móra Kiadó.

Gyöngyösiné, K. E. (2007). Az önmegvalósítás és pozitív önértékelés szükségletei Maslow és Rogers pszichológiájában. In Oláh, A. (Ed.), Vázlatok a személyiségről - a személyiséglélektan alapvető irányzatainak tükrében (pp. 381-383). Új Mandátum Könyvkiadó.

Hattie, J. (2008). Visible learning - A Synthetics Of Over 800 Meta-Analyses Relating To Achievement. Routhledge. https://doi.org/10.4324/9780203887332

Hamvai, Cs., \& Pikó, B. (2008). Pozitív pszichológiai szempontok az iskola világában: a pozitív pedagógia kihívásai. Magyar Pedagógia, 108(1), 71-92.

Hercz, M. (2008). Professzionális tanárképzés az Európai Unióban 1.: Finnország, Hollandia, Németország és az Egyesült Királyság példája. Iskolakultúra, 3(4), 96-123.

Holecz, A. \& Molnár, Sz. (2014). Pedagógusok pozitív pszichológiai tükörben: a jóllétet erősítő tényezők jellemzői a pályán. Iskolakultúra, 14(10), 3-14.

Horváth, A. (1996). Elméletek a nevelésröl. Okker Kiadó.

Hunyadyné., \& M. Nádasi, M. (2008). Fekete pedagógia - a szociális életképesség megalapozásának iskolai akadályai. In Bábosik, I. \& Koncz, I. (Eds.), A szociális életképesség megalapozása az iskolában (pp. 31-45). PEM.

Jerusalem, M., \& Pekrun, R. (1999, Eds.). Emotion, Motivation und Leistung. Hogrefe Verlag.

Kálmán, O. (2008). A pedagógus szakma és a pedagógusképzés Finnországban. Szakmai beszámoló a Joensuu-i tanulmányútról. 2008. március 31. - április. 4.

Kolosai, N., \& Bognár, T. (2007). Pedagógusok mentálhigiénéje. In Bollókné Panyik, I. (Ed.), Gyermek-Nevelés-Pedagógusképzés (pp. 33-51). Trezor Kiadó.

Kun, Á., \& Szabó, A. (2017). Boldogság tényezők a pedagógusok munkájában. Magyar Pszichológiai Szemle, 72(3), 281-310. https://doi.org/10.1556/0016.2017.001

Mihály, I. (2003). Világraszóló oktatási sikerek, és ami mögöttük van - A PISA vizsgálat eredményeiről. Új Pedagógiai Szemle, 53(12), 92-94.

Mirnics, Zs. (2006). A személyiség építőkövei. Bölcsész konzorcium.

Nagy H., \& Gyurkovics M. (2016). A pszichológiai jóllét szociodemográfiai korrelátumai, kapcsolata a big five vonásokkal és az optimizmussal. Mentálhigiéné és Pszichoszomatika, 17(3), 195-214. https://doi.org/10.1556/0406.17.2016.001 
Ónody, S. (2001). Kiégési tünetek (burnout szindróma) keletkezése és megoldási lehetőségei. Új Pedagógiai Szemle, 51(5), 81-85.

Paksi, B., \& Smidt, A. (2006). Pedagógusok mentálhigiénés állapota. Új Pedagógiai Szemle, 56(6), 48-64.

Paksi, B., Veroszta, Zs., Schmidt, A., Magi, A., Vörös, A., Endrődi-Kovács, V., \& Felvinczi, K. (2015). Pedagógus-pálya-motiváció. Egy kutatás eredményei. Oktatási Hivatal.

Petróczi, E., Fazekas, M., Tombácz, Zs., \& Zimányi M. (1999). A kiégés jelensége pedagógusoknál. Magyar Pszichológiai Szemle, 54(3), 429-441.

Réthy, Ené. (2016). Miért fontos a tanárok kiegyensúlyozott érzelmi élete, elégedettsége, jólléte? Iskolakultúra, 26(29), 88-99.

Ryan, R. M., \& Deci, E. L. (2000). Self-determination theory and the facilitation of intrinsic motivation, social development, and well-being. American Psychologist, 55(1), 68-78. https://doi.org/10.1037/0003-066X.55.1.68

Rogers, C. R., Lyon, H. C., \& Tausch, R. (2013). On Becoming an Effective Teacher. Routledge. https://doi.org/10.4324/9780203725672

Ryff, C. D., \& Keyes, C. L. M. (1995). The structure of psychological- well-being revisited. Journal of Personality and Social Psychology, 69(4), 719-727. https:// doi.org/10.1037/0022-3514.69.4.719

Rosenthal, R., \& Jacobson, L. (1968). Pygmalion in the classroom: Teacher expectation and pupils' intellectual development. Rinehart \& Winston.

Rushton, S., Morgan, J., \& Richard, M. (2007). Teacher's Myers-Briggs personality profile: Identifying effective teacher personality traits. Teaching and Teacher Education, 23(4), 432-441. https://doi.org/10.1016/j.tate.2006.12.011

Sallai, É. (2004). Pedagógusnak lenni a mai iskolában. IV. Országos Osztályfönöki Konferencia. www.osztalyfonok.hu/cikk.php?id=230.

Szántó, Zs., Susánszky, É., Berényi, Z., Sipos, F., \& Murányi I. (2016). A jól-lét fogalmának értelmezése az európai szakirodalomban (2009-2014). Metszetek, 5(1), 16-32. https://doi.org/10.18392/metsz/2016/1/6

Szebeni, R. (2010). A kompetencia alapú oktatás pedagógus személyiség háttere. Debreceni Egyetem Bölcsészettudományi Kar Humán Tudományok Doktori Iskola. https://dea.lib.unideb.hu/dea/bitstream/handle/2437/109141/\%C3\%89rt ekez\%C3\%A9s.pdf? sequence $=5 \&$ is Allowed $=\underline{y}(2020.07 .31$. $)$

Schmid, P. F. (2001). Authenticity: the person as his or her own author: Dialogical and ethical perspectives on therapy as an encounter relationship. Wyatt, Gill (Ed.), Congruence, Llongarron, Ross-on-Wye (PCCS Books), 201-216. (Series „Rogers' therapeutic conditions. Evolution, theory and practice”)

Stern, D. N. (1977). The first relationship: mother and infant. Harvard University Press. Suplicz, S. (2012). Tanárok pszichológiai jellemzői diákszemmel. Doktori disszertáció. Debreceni Egyetem. 
Szebeni, R. (2010). A kompetencia alapú oktatás személyiség háttere. Doktori értekezés, DTE.

Tókos, K. (2005). Az önismeret-jelenismeret tanítója, fejlesztője: az „új arcú”, reflektív pedagógus. Új Pedagógiai Szemle, 55(12), 65-71.

World Health Organization (1998). WHOQOL and spirituality, religiousness and personalbeliefs: Reporton WHO consultation. WHO. 


\section{Borbáth, K.}

\section{Thoughts about aspects and effects of teacher's psychological well-being}

Schools are penetrated by emotions, amongst teacher's emotions which are remarkably influencing school climate and even students' achievements. The growing in terest for this topic showed by the existence of numerous examinations on traits of teachers' mental hygiene in a differentiated way, there are traditionally burn out orientated and lately psychological well-being researches. The actual part of these examinations, especially Hungarian ones is in the middle of the study. The focus is the relevant results of the researches about the emotional background of the teach ers' occupational and personal life, including the links between the danger of burning out and life orientation, psychological knowledge, self-knowledge, specialisation and capableness for flow on lessons. The article shows the process, that is happening in the meantime in the field of the researches on teachers' personality traits , that are ascending as a more remarkable area for education science. In this field, -thanks for the powerful impacts of theories of positive psychology and personal psychology on educational studies -it has become obvious that, teachers' personality traits, the personal and the occupational self are important parts of teachers' identity. Finally, -finding links between teachers' emotional states and certain aspects of teachers' training- this study touches main components of the Finnish teacher' training model, the one of the most successful model, that is nowadays referred as an ideal. The main factor of the Finnish model for us is that there practical educational tools exist for growing awareness of teacher's own identity, and shaping occupational self. It is different from Hungary, where those efforts for understanding concepts of self -knowledge, occupational self are more theoretical ones.

Keywords: pedagogue, burning out, psychological well-being 